\title{
GAMBARAN KARAKTERISTIK MAHASISWA DAN ALUMNI FARMASI FKIK UIN ALAUDDIN MAKASSAR : SEBUAH TINJAUAN BERBASIS GENDER
}

\author{
Asrul Ismail* \\ *Dosen Jurusan Farmasi \\ FKIK UIN Alauddin \\ Makassar \\ Email: asrul.ismail@uin-alauddin.ac.id
}

\begin{abstract}
Abstrak:
Stereotip masyarakat tentang pendidikan farmasi yang didominasi oleh perempuan sudah lama berkembang. Beragam universitas di Indonesia telah menyediakan pendidikan sarjana farmasi, salah satunya adalah UIN Alauddin Makassar. Jurusan Farmasi UIN Alauddin Makassar telah menerima mahasiswa sejak tahun 2005 hingga sekarang. Penelitian ini bertujuan untuk memberikan gambaran karakteristik mahasiswa dan alumni Jurusan farmasi FKIK UIN Alauddin Makassar dari perspektif gender. Penelitian didesain secara deskriptif dengan metode cross sectional. Jumlah sampel sebanyak 174 orang yang terdiri mahasiswa dan alumni dari berbagai angkatan. Hasil penelitian menunjukkan bahwa jenis kelamin perempuan masih mendominasi sebanyak 75.3\%(131), sedangkan laki-laki sebanyak 24.7\% (43). Dalam memilih jurusan farmasi, terdapat 10.9\% (19) yang mempertimbangkan jenis kelamin sedangkan yang memilih tidak sebesar 89.1\% (155). Hal ini kontradiktif dengan pendapat masing - masing responden yang memilih adanya pengaruh jenis kelamin dalam pemilihan jurusan $50.6 \%$ (88) dan yang memilih tidak sebanyak 49.4\% (86). Persepsi tentang adanya keharusan sebuah jurusan didominasi oleh jenis kelamin tertentu sebesar 50.6\% (88) dan tidak harus sebesar $49.4 \%$ (86). Terdapat 90.8\% (158) yang berpendapat bahwa semua jenis kelamin memiliki kesempatan yang sama untuk berkuliah dan memilih jurusan tertentu dan 9.2\% (16) menjawab tidak. Terdapat $68.4 \%$ (119) yang berpendapat bahwa jenis kelamin berpengaruh terhadap pekerjaan, sedangkan 31.6\% (55) menjawab tidak.
\end{abstract}

Kata kunci: Gender, Farmasi, Karakteristik, Pendidikan, Pekerjaan

\section{PENDAHULUAN}

Ilmu farmasi sudah lama berkembang bahkan sejak zaman sebelum masehi. Kata Farmasi berasal dari bahasa Yunani, yaitu kata Pharmacon yang berarti racun atau obat. Ilmu Farmasi merupakan ilmu yang mempelajari segala aspek tentang obat-obatan secara mendalam meliputi bidang penemuan obat, pengembangan obat, produksi obat, pengolahan, peracikan, pemberian informasi obat, penggunaan obat dalam terapi (farmakoterapi), dan distribusi obat. Ilmu kefarmasian belum dikenal oleh dunia pada zaman Hiprocrates (bapak ilmu kedokteran) yaitu pada tahun 460 SM sampai dengan 370 SM . Pada masa itu 
dokter atau tabib memiliki banyak tugas tidak hanya mendiagnosa suatu penyakit yang diderita oleh pasien, melainkan juga harus mempersiapkan racikan obat dan ramuan tertentu seperti halnya seorang apoteker masa kini.

Seiring dengen perkembangan zaman dan ilmu pengetahuan di bidang kesehatan, masalah-masalah dalam pengelolaan obat menjadi semakin kompleks, termasuk pada aspek formulasi, penyimpanan dan distribusi obat. Hal ini dianggap sebagai masalah tersendiri mengingat terbatasnya sumber daya yang ada pada saat itu, sehingga dibutuhkanlah seseorang yang dapat mendalami keahlian dalam formulasi dan peracikan obat. Pada tahun 1240 SM Raja Jerman Frederick menyadari hal tersebut dan secara resmi memberikan perintah untuk memisahkan ilmu Kedokteran dan Ilmu Farmasi. Perintah tersebut dikenal dengan Dektrit Two Silices. Pada awalnya obat hanya digunakan berdasarkan pengalaman secara empirik dari tumbuhan. Pada akhir abad 19, obat masih merupakan produk organik atau anorganik dari tumbuhan yang dikeringkan atau segar, Bahan bahan tersebut efektif dalam penyembuhan penyakit tetapi dapat juga menimbulkan efek toksik bila dosisnya terlalu tinggi. Hal ini menjadikan ilmu farmasi semakin dibutuhkan dan memiliki kekhasan tersendiri (Sukandar, 2016).

Tonggak sejarah ilmu farmasi di Indonesia dimulai dengan didirikannya Perguruan Tinggi Farmasi di Klaten pada tahun 1946, yang kemudian menjadi Fakultas Farmasi UGM, dan setahun kemudian di Bandung pada tahun 1947. Lembaga Pendidikan Tinggi Farmasi yang didirikan pada masa perang kemerdekaan ini mempunyai andil yang besar bagi perkembangan sejarah kefarmasian pada masa-masa selanjutnya. Dengan pesatnya perkembangan ilmu kefarmasian, maka farmasis saat ini menempati ruang lingkup pekerjaan yang makin luas. Beberapa tempat pekerjaan kefarmasian antara lain adalah di apotek, rumah sakit, lembaga pemerintahan, perguruan tinggi, lembaga penelitian, laboratorium pengujian mutu, laboratorium klinis, laboratorium forensik, berbagai jenis industri farmasi meliputi industri obat, kosmetik-kosmeseutikal, jamu, obat herbal, fitofarmaka, nutraseutikal, health food, obat veteriner dan industri vaksin, lembaga informasi obat serta badan asuransi kesehatan (Ikawati,2010). 
Cakupan tempat pekerjaan di bidang farmasi yang begitu luas serta masih belum ideal dan meratanya jumlah apoteker di Indonesia melahirkan tantangan tersendiri bagi pengelola isntitusi pendidikan farmasi. Data Asosiasi Perguruan Tinggi Farmasi Indonesia (APTFI) menunjukkan jumlah farmasis di Indonesia saat ini masih kurang dari 10.000 sehingga rasio terhadap penduduk Indonesia lebih kurang 1:20.000. Peningkatan minat pendaftar lulusan sekolah menengah atas (atau yang sederajat) dapat menjadi harapan tersendiri akan terpenuhinya rasio ideal farmasis di masa yang akan datang.

Meskipun demikian, terdapat fakta lapangan adanya fenomena menarik mengenai pergesaran komposisi gender pada mahasiswa fakultas farmasi di beberapa perguruan tinggi di Indonesia. Sebuah studi lapangan menunjukkan bahwa perbandingan antara laki-laki dan perempuan yang menjadi mahasiswa program studi farmasi UGM dan USD mengalami pergeseran komposisi. Pada tahun ajaran 1995 sampai 2000 perbandingan rasio laki-laki dan perempuan tidaklah terlalu timpang. Pada tahun tersebut di UGM hanya berkisar 1:3; sementara USD sebesar 1:2. Pada tahun setelah 2010 terjadi kenaikan rasio ketimpangan di USD masih berkisar 1:3, sedangkan di UGM terjadi peningkatan yang berarti. Pada tahun 2011, ketimpangan yang terjadi di UGM mencapai angka 1:5, bahkan melonjak menjadi 1:8 pada tahun 2012, dan pada tahun 2016 menjadi 1:6 (Najah, 2016).

Jurusan Farmasi Fakultas Kedokteran dan Ilmu Kesehatan UIN Alauddin Makassar didirikan pada tahun 2004, dan mulai melaksanakan penerimaan mahasiswa baru sejak tahun 2005 dengan rasio perempuan lebih banyak dibandingkan dengan laki - laki. Hal ini tetap berlangsung hingga saat ini. Hal tersebut menjadi fenomena yang menarik untuk dikaji, mengingat fakta di bidang pekerjaan kefarmasian yang beragam. Perbedaan jenis kelamin antara laki - laki dan perempuan saat ini dinilai berpotensi dapat memengaruhi kesesuaian jenis pekerjaan pada seseorang, termasuk dalam pekerjaan kefarmasian. Penelitian ini bertujuan untuk memberikan gambaran karakteristik mahasiswa dan alumni farmasi FKIK UIN Alauddin Makassar ditinjau dari aspek gender. 


\section{TINJAUAN PUSTAKA}

\section{Pendidikan dan Gender}

Pendidikan yang dahulunya merupakan hal yang langka di kehidupan masyarakat Indonesia, kini semakin diketahui urgensinya bagi kemajuan bangsa. Pendidikan dianggap sebagai pengubah kejiwaan manusia atau yang lebih dikenal sebagai memanusiakan manusia. Pendidikan juga merupakan langkah awal untuk mempersiapkan manusia menjalani dunia kerja maupun dunia bermasyarakat. Ada beberapa pengertian pendidikan menurut para ahli yang tercantum di dalam buku Filsafat Pendidikan karya Yunus1, diantaranya menurut Prof. Herman H. Horn, yang mengatakan "Pendidikan adalah proses abadi dari penyesuaian lebih tinggi bagi makhlukyang telah berkembang secara fisk dan mental yang bebas dan sadar kepada Tuhan seperti termanifestasikan dalam alam sekitar, intelektual, emosional dan kemauan dari manusia (Natasha,2013).

Sedangkan menurut Undang-undang no 12 tahun 2012 menyatakan bahwa: Pendidikan adalah usaha sadar dan terencana untuk mewujudkan suasana belajar dan proses pembelajaran agar peserta didik secara aktif mengembangkan potensi dirinya untuk memiliki kekuatan spiritual keagamaan, pengendalian diri, kepribadian, kecerdasan, akhlak mulia serta keterampilan yang diperlukan dirinya, masyarakat, bangsa dan negara.

Dalam lintasan sejarah, setiap kelompok masyarakat mempunyai konsepsi ideologis tentang jenis kelamin. Di beberapa kelompok ma $\neg$ syarakat, jenis kelamin digunakan sebagai kriteria yang penting dalam pembagian kerja. Kelompokkelompok masyarakat tersebut membagi peran, tugas dan kerja berdasarkan jenis kelamin, meskipun sebagaian di antaranya ada yang dipandang cocok dan wajar untuk dilakukan oleh kedua jenis kedua jenis kelamin (Khotimah, 2009).

Pekerjaan yang diperuntukkan bagi laki-laki umumnya yang diาanggap sesuai dengan kapasitas biologis, psikologis, dan sosial sebagai laki-laki, yang secara umum dikonsepsikan sebagai orang yang memiliki otot lebih kuat, tingkat resiko dan bahayanya lebih tinggi karena bekerja di luar rumah, dan tingkat keterampilan dan kerjasamanya lebih tinggi Adapun pekerjaan yang diperuntukkan bagi perempuan yang dikon $\neg$ sepsikan sebagai orang yang lemah 
dengan tingkat resiko lebih rendah, cenderung bersifat mengulang, tidak memerlukan konsentrasi, dan lebih mudah terputus-putus. Oleh karena itu, tingkat keterampilan perempuan dianggap rata-rata lebih rendah di banding lakilaki (Khotimah, 2009).

Menurut penelitian George Peter Murdock, laki-laki lebih konsisten kepada pekerjaan maskulin yaitu memburu binatang, mengerjakan logam, melebur bijibiji, pekerjaan soldir, pertukangan kayu, membuat instrumen musik, menangkap dengan perangkap, membuat kapal, pertukangan batu, mengerjakan tulangtulang, tanduk dan kulit kering, menambang, dan mengangkut. Perempuan lebih konsisten kepada pekerjaan feminin, yaitu mengumpulkan bahan bakar (kayu), mem $\neg$ persiapkan minuman, meramu dan menyediakan bahan makanan dari tumbuhan-tumbuhan liar, produksi bahan susu, mencuci, mengambil air dan memasak, dan pekerjaan rumah tangga lainnya (Khotimah, 2009).

Secara umum substansi pola publik domestik masih dipertahankan, karena partisipasi perempuan masih dihargai lebih rendah daripada laki-laki. Lagipula, perempuan masih lebih umum dialokasikan pada bidang-bidang tertentu seperti pekerjaan tulis-menulis, kesekretariatan, jasa, dan yang berhubungan dengan kegiatan pengasuhan dan perawatan seperti guru, perawat. Masih sangat sedikit perempuan yang masuk di dalam lingkaran profesional dan eksekutif. Laki-laki masih tetap dominan di sektor profesi yang memiliki status lebih tinggi, seperti teknik, arsitek, dokter, kontraktor, manajer, dan lain sebagainya. Laki-laki mendominasi industri hulu yang produktivitasnya lebih tinggi, sementara perempuan terlibat dalam industru hilir, yang menangani proses akhir dari sebuah produk (finishing), yang upah produktivitasnya lebih rendah. Tegasnya, dalam masyarakat industri, pembagian kerja secara seksual, cenderung dipertahankan. Pola relasi masih berlangsung tidak seimbang, dan dengan demikian status dan kedudukan perempuan masih lemah (Khotimah, 2009).

\section{Pendidikan dan Perkembangan Bidang Kefarmasian}

Pelayanan kefarmasian saat ini telah semakin berkembang selain berorientasi kepada produk (product oriented) juga berorientasi kepada pasien (patient oriented) seiring dengan peningkatan kesadaran masyarakat akan 
pentingnya kesehatan dan pergeseran budaya rural menuju urban yang menyebabkan peningkatan dalam konsumsi obat terutama obat bebas, kosmetik, kosmeseutikal, health food, nutraseutikal dan obat herbal (Sukandar,2016).

Berbagai tuntutan yang ada di masyarakat menjadi tantangan untuk pengembangan dunia kefarmasian seperti : Pharmaceutical care yaitu obat sampai ketangan pasien dalam keadaan baik, efektif dan aman disertai informasi yang jelas sehingga penggunaannya tepat dan mencapai kesembuhan; timbulnya penyakit baru dan perubahan pola penyakit yang memerlukan pencarian obat baru atau obat yang lebih unggul ditinjau dari efektivitas dan keamanannya; meningkatnya penyalagunaan obat dan ketergantungan pada narkoba dan psikotropika merupakan tuntutan untuk dapat mengawasi penggunaan obat tersebut, mencari/mensintesis obat yang lebih aman dan mampu memberikan informasi tentang bahaya penyalahgunaan obat; farmasis sebagai partner dokter memacu farmasis untuk menguasai lebih mendalam ilmu farmakologi klinis dan farmakoterapi serta ilmu farmasi sosial dan komunikasi; farmasis sebagai penanggung jawab pengadaan obat di apotek, rumah sakit, pedagang besar farmasi, puskesmas dll. harus menguasai farmakoekonomi dan manajemen farmasi; tuntutan farmasis untuk dapat berperan dalam perkembangan industri Farmasi perkembangan drug delivery system, pengembangan cara produksi dan metode control kualitas; farmasis untuk menempati bidang pemerintahan yang berfungsi dalam perizinan, pengaturan, pengawasan, pengujian, pemeriksaan dan pembinaan; perkembangan farmasi veteriner, perkembangan medical devices (alat kesehatan, pereaksi diagnostik) (Sukandar,2016). Keragaman potensi pekerjaan farmasis menimbulkan stereotip kesesuaian gender dalam bidang tertentu dalam praktik kefarmasian.

\section{METODE PENELITIAN}

\section{Populasi Penelitian}

Populasi adalah semua mahasiswa dan alumni Jurusan Farmasi FKIK UIN Alauddin Makassar pada periode April 2020. 


\section{Sampel Penelitian}

Sampel adalah data mahasiswa dan alumni Jurusan Farmasi FKIK UIN Alauddin Makassar yang memenuhi kriteria inklusi, yaitu mahasiswa dan alumni yang menyetujui untuk dilibatkan sebagai subyek dalam penelitian ini dengan mengisi kuesioner sebanyak 174 responden.

\section{Tahap Persiapan Penelitian}

Pada tahap persiapan ini akan diawali dengan studi kepustakaan, dan mengumpulkan informasi terkait pendidikan farmasi dan informasi gender yang dibutuhkan.

\section{Tahap Pelaksanaan Penelitian}

Tahap penelitian dimulai dari pengambilan dan pengelompokkan sampel. Pengambilan sampel berdasarkan dari distribusi angkatan masuk mahasiswa dan alumni yang memenuhi kriteria inklusi. Data yang diamati berupa data karakteristik angkatan, jenis kelamin, dan status pekerjaan yang diperoleh dari survey dan dicatat melalui lembar pengumpulan data (google form).

\section{Pengolahan Data}

Setelah semua data didapatkan, selanjutnya dilakukan tabulasi berdasarkan kriteria yang sudah ditentukan. Data yang diperoleh dilakukan pengolahan data dengan cara editing, coding, entry data, tabulasi dengan menggunakan komputer.

\section{Analisis Data}

Analisis data dilakukan berdasarkan hasil penelitian dengan menggunakan metode statistik deskriptif yang menggambarkan sebaran dan jumlah karakteristik mahasiswa dan alumni farmasi.

\section{HASIL DAN DISKUSI}

Karakteristik mahasiswa dan alumni Jurusan Farmasi FKIK UIN Alauddin Makassar dalam penelitian ini adalah data hasil survey yang terbagi menjadi 3 yaitu: angkatan masuk, jenis kelamin dan status pekerjaan. 


\section{Sebaran berdasarkan angkatan masuk}

Karakteristik mahasiswa dan alumni berdasarkan angkatan masuk yang mengisi survey dapat dilihat pada diagram dibawah ini :

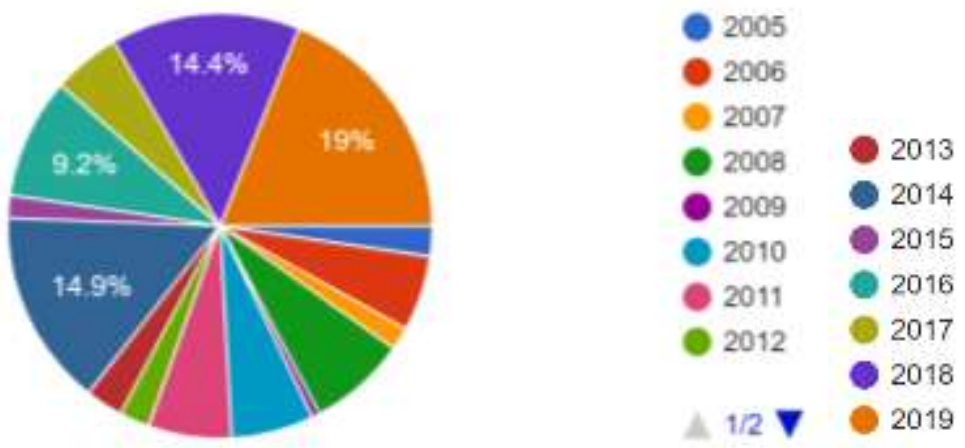

Gambar 1. Diagram sebaran berdasarkan angkatan masuk

Subyek penelitian yang bersedia terlibat terdiri dari angkatan 2005 sebanyak 4 orang (2.3\%), angkatan 2006 sebanyak 10 orang (5.7\%), angkatan 2007 sebanyak 3 orang (1.7\%), angkatan 2008 sebanyak 13 orang (7.5\%), angkatan 2009 sebanyak 1 orang (0.6\%), angkatan 2010 sebanyak 11 orang (6.3\%), angkatan 2011 sebanyak 11 orang (6.3\%), angkatan 2012 sebanyak 4 orang (2.3\%), angkatan 2013 sebanyak 5 orang (2.9\%), angkatan 2014 sebanyak 26 orang (14.9\%), angkatan 2015 sebanyak 3 orang (1.7\%), angkatan 2016 sebanyak 16 orang (9.2\%), angkatan 2017 sebanyak 9 orang (5.2\%), angkatan 2018 sebanyak 25 orang (14.4\%), dan angkatan 2019 sebanyak 33 orang (19\%). Data menunjukkan bahwa sebaran subjek penelitian dalam tiap angkatan sangat beragam. Meskipun demikian setiap angkatan memiliki perwakilan untuk terlibat dalam mengisi survey dalam penelitian ini sehingga keterwakilan setiap angkatan dapat diterima.

\section{Sebaran berdasarkan jenis kelamin}

Karakteristik mahasiswa dan alumni berdasarkan jenis kelamin yang mengisi survey dapat dilihat pada diagram dibawah ini : 


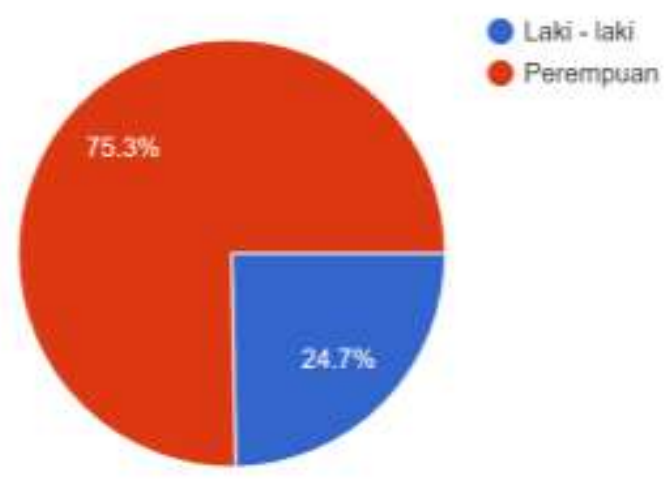

Gambar 2. Diagram sebaran berdasarkan jenis kelamin

Subyek penelitian yang bersedia terlibat terdiri dari laki - laki sebanyak 43 orang $(24.7 \%)$, dan perempuan sebanyak 131 orang (75.3\%). Secara keseluruhan sejak Jurusan Farmasi FKIK UIN Alauddin Makassar menerima mahasiswa baru, data menunjukkan bahwa jenis kelamin perempuan lebih banyak dibandingkan dengan jenis kelamin laki - laki, dengan perbandingan 1:3. Hal ini serupa dengan penelitian lapangan yang telah dilakukan oleh Najah (2016) mengenai pergeseran gender mahasiswa farmasi UGM dan USD yang menyebutkan bahwa dari tahun ke tahun jumlah perempuan kian mendominasi dari total jumlah mahasiswa.

Terdapat beberapa faktor yang dapat memengaruhi fenomena tersebut, antara lain : 1) Proses perkuliahan dan lapangan pekerjaan di farmasi membutuhkan ketelitian yang tinggi. Terdapat stereotip yang menghubungkan antara tingkat ketelitian yang tinggi dengan jenis kelamin perempuan. 2) Adanya faktor biologis, yaitu perbedaan jenis hormon yang dominan pada perempuan dan laki - laki. Perempuan didominasi oleh hormon estrogen dan progesterone yang berdampak terhadap sifat feminism, sedangkan laki - laki didominasi oleh hormone testosterone yang menunjukkan sifat maskulinitas. Sebuah penelitian yang dilakukan oleh Kurniasari (2015) menunjukkan bahwa pekerjaan yang berhubungan dengan maskulin dipersepsi lebih sesuai untuk jenis kelamin laki laki. Sedangkan untuk pekerjaan yang berhubungan dengan feminism dipersepsi lebih sesuai untuk perempuan.

Maskulinitas dimisalkan dengan pekerjaan yang berhubungan dengan dunia malam, otot, tenaga, dan berpetualang. Salah satu contoh yang dapat dilihat dalam sehari - hari adalah petugas keamanan, dan driver. Sebaliknya, Feminisme 
dimisalkan dengan pekerjaan yang berhubungan dengan kesabaran, dan ketelitian. Sebagai contoh profesi tersebut adalah perawat dan hair styles. Meskipun demikian terdapat beberapa profesi yang dapat dikerjakan oleh laki laki maupun perempuan.

Pekerjaan kefarmasian yang dilaksanakan oleh farmasis (apoteker) secara umum adalah pengkajian resep (administrasi, farmasetik dan pertimbangan klinis), dispensing, pelayanan informasi obat, konseling, home pharmacy care, pemantauan terapi obat dan monitoring efek samping obat. Pekerjaan tersebut membutuhkan tingkat ketelitian yang tinggi, kesabaran dan bahkan dalam kasus tertentu juga membutuhkan kesesuaian logika berdasarkan evidence based medicine. Hal ini dapat mengarahkan opini bahwa pekerjaan kefarmasian yang menekankan ketelitian lebih cocok pada jenis kelamin perempuan. Meskipun demikian, kurikulum disusun dengan tidak membedakan jenis kelamin, dan ketelitian dapat dilatih dan dipelajari oleh perempuan dan laki - laki. Selain itu, jika teknis pekerjaan tersebut dijabarkan satu persatu, konsep maskulinitas dan feminism justru tampak melebur dan saling melengkapi, sehingga baik laki - laki maupun perempuan memiliki kecocokan yang sama dalam pekerjaan ini. Akan tetapi hal tersebut tidak membantah fakta bahwa jumlah mahasiswa perempuan lebih banyak dibandingkan laki - laki.

\section{Sebaran berdasarkan status pekerjaan}

Karakteristik mahasiswa dan alumni berdasarkan status telah bekerja atau tidak dapat dilihat pada diagram dibawah :

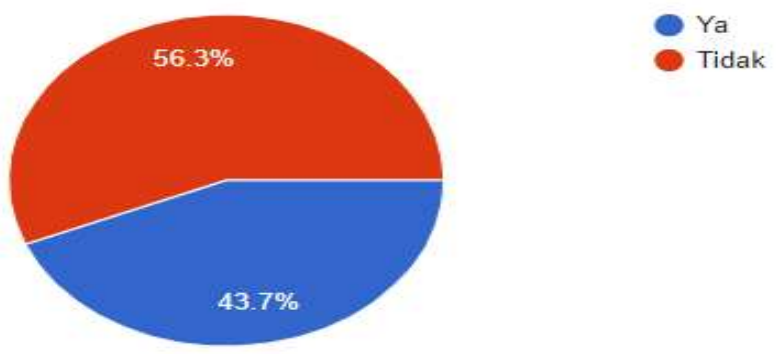

Gambar 3. Diagram sebaran berdasarkan status pekerjaan

Subyek penelitian yang telah memiliki pekerjaan sebanyak 76 orang (43.7\%) dan yang belum bekerja sebanyak 98 orang (56.3\%). Keseluruhan responden yang memiliki pekerjaan telah berstatus alumni, dan kini telah bekerja 
diberbagai instansi pemerintah maupun swasta. Sedangkan responden yang memilih belum bekerja adalah mahasiswa dengan status aktif. Berdasarkan hasil survey pada alumni yang telah bekerja, beberapa diantaranya memiliki pendapat bahwa jenis kelamin tidak berpengaruh terhadap pekerjaan yang ditekuni, dalam hal ini adalah pekerjaan kefarmasian. Hal ini dapat dilihat pada diagram berikut :

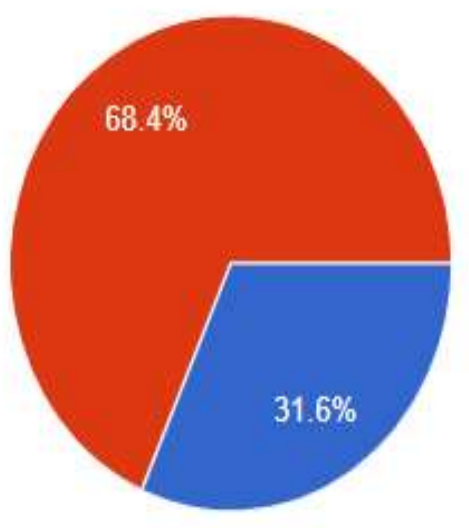

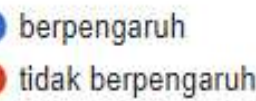

tidak berpengaruh

Gambar 4. Diagram pengaruh jenis kelamin terhadap pekerjaan

Responden yang menganggap bahwa terdapat pengaruh jenis kelamin terhadap pekerjaannya sebesar $31.6 \%$, sedangkan yang tidak sebesar $68.4 \%$. Hal ini menunjukkan bahwa mayoritas pekerjaan kefarmasian cenderung dapat dikerjakan oleh keduanya.

\section{Persepsi Gender Terhadap Pemilihan Jurusan}

Pada penelitian ini, responden diberikan pertanyaan mengenai ada tidaknya persepsi gender tertentu dalam pemilihan jurusan ketika akan berkuliah, dan hasilnya dapat dilihat pada diagram dibawah :

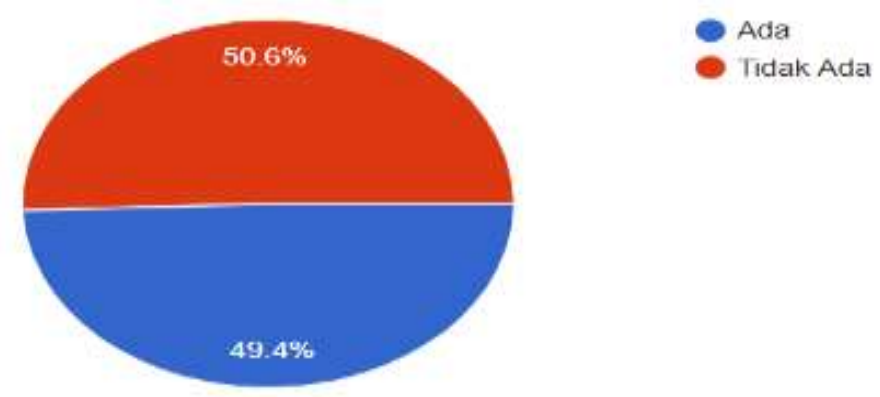

Gambar 5. Diagram pengaruh jenis kelamin terhadap pemilihan jurusan 


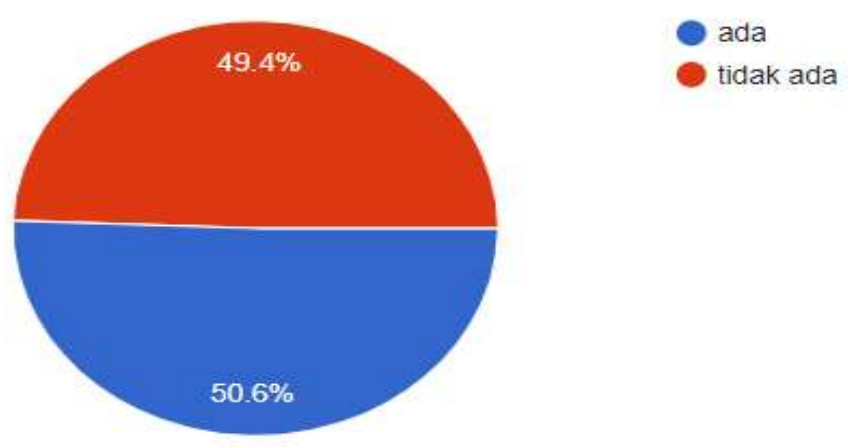

Gambar 6. Diagram kekhasan gender tertentu suatu jurusan

Responden yang menganggap bahwa tidak ada pengaruh jenis kelamin terhadap pemilihan jurusan kuliah (gambar 5), yaitu sebesar 50.6\% (88), sedangkan yang menganggap ada pengaruh sebesar $49.4 \%$ (86). Hal ini hampir sejalan dengan pendapat responden mengenai adanya persepsi kekhasan gender tertentu suatu jurusan (gambar 6). 50,6\% menganggap ada, sedangkan 49.4\% menganggap tidak ada. Sebagai contoh jurusan pada bidang ilmu teknik dianggap lebih cocok dengan jenis kelamin laki - laki, sedangkan jurusan pada bidang ilmu kesehatan dianggap lebih cocok dengan jenis kelamin perempuan.

Meskpun demikian dalam memilih jurusan farmasi, responden cenderung tidak mempertimbangkan jenis kelamin dan menganggap bahwa semua gender memiliki kesempatan yang sama dalam memilih jurusan kuliah. Hal ini dapat dilihat pada diagram berikut :

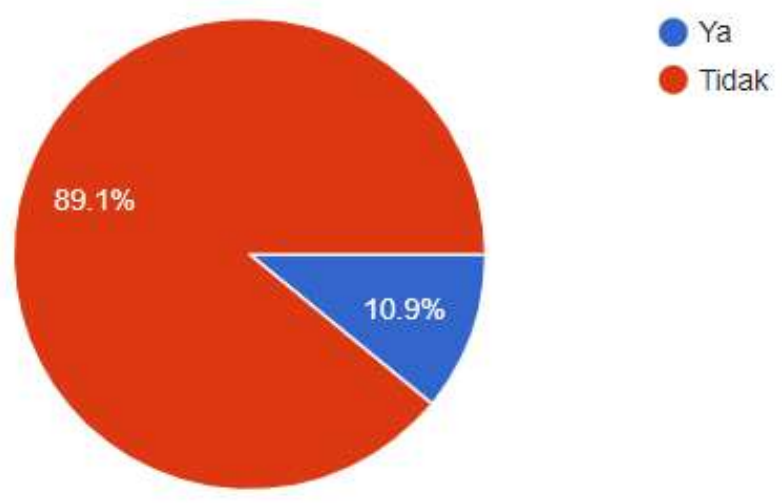

Gambar 7. Diagram pertimbangan gender dalam memilih jurusan farmasi 


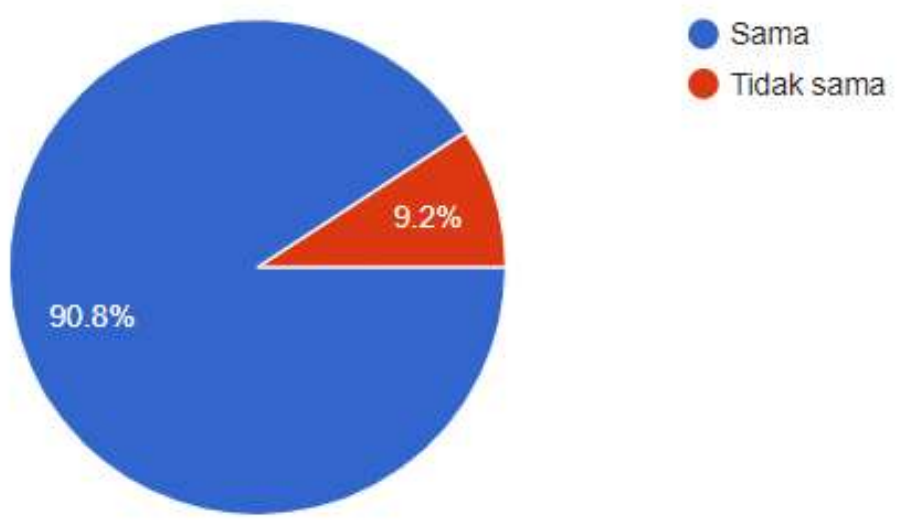

Gambar 8. Diagram gender memiliki kesempatan yang sama dalam memilih jurusan kuliah

Responden yang mempertimbangkan gender dalam memilih jurusan farmasi sebanyak 19 orang (10.9\%), sedangkan yang memilih jurusan farmasi tanpa mempertimbangkan gender sebanyak 155 orang (89.1\%) (Gambar.7). Hal ini cenderung sejalan dengan data responden yang menganggap bahwa semua gender memiliki kesempatan yang sama dalam memilih jurusan, yaitu sebanyak 158 orang $(90.8 \%)$, dan yang tidak sebanyak 16 orang (9.2\%) (gambar 8). Ini berarti meskipun responden masih memiliki stereotip tentang adanya pengaruh gender terhadap pemilihan jurusan kuliah dan adanya kekhasan gender untuk jurusan tertentu, pada kenyatannya pertimbangan gender dalam memilih jurusan tidak berpengaruh, sehingga dapat dianggap bahwa setiap gender memiliki kesempatan yang sama dalam pendidikan, khususnya pendidikan farmasi.

\section{KESIMPULAN}

Gambaran karakteristik mahasiswa dan alumni Farmasi UIN Alauddin Makassar terdiri dari mayoritas perempuan, dengan perbandingan 1:3. Gender dianggap tidak memengaruhi proses pendidikan maupun pekerjaan. Saran, dibutuhkan penelitian yang lebih mendalam dengan jumlah sampel yang lebih besar. 


\section{DAFTAR PUSTAKA}

Ikawati, Zullies. (2010) : Pelayanan Farmasi Klinik Pada Era Genomik : Sebuah Tantangan dan Peluang; Universitas Gadjah Mada, Yogyakarta.

Khotimah, Khusnul. (2009) : Diskriminasi Gender Terhadap Perempuan dalam Sektor Pekerjaan, Yin Yang Jurnal Studi Gender dan Anak, Volume 4 Nomor 1 pp.158-180.

Kurniasari, Netty. Diah. (2015): Sex Role, Bias Gender dan Pekerjaan, Jurnal Pamator Volume 8 Nomor 1; hal: 47-45.

Najah, Hakam. (2016): Analisis Gender dalam Pergeseran Komposisi Gender Mahasiswa Farmasi; Lustrum Farmasi UGM ke-XIV, Universitas Gadjah Mada, Yogyakarta.

Natasha, Harum. (2013) : Ketidaksetaraan Gender Bidang Pendidikan: Faktor Penyebab, Dampak, Dan Solusi, Marwah Jurnal Perempuan, Agama dan Gender, Volume 12 Nomor 1

Sukandar, Elin. Yulinah. (2016) : Trend dam paradigma dunia farmasi, Departemen Farmasi, FMIPA Institut Teknologi Bandung, Bandung.

Undang-undang no 12 tahun 2012. Diunduh dari: http://riau.kemenag.go.id/file/file/produkhukum/faiz1360854336.pdf 